\title{
Reinsurance Intermediaries: A Comparison of the EU and U.S. Regulatory Approach*
}

\author{
Pierpaolo Marano \\ University of Calabria, Via Guglielmo Tocci, 2/b, Cosenza, Cosenza 87100, Italy. \\ E-mail: pp.marano@unical.it
}

Directive 2002/92/EC on insurance mediation holds very few provisions on reinsurance intermediaries whose discipline is in the hands, in large part, of each Member State. This lack of harmonized rules is inconsistent with the transnational nature of the reinsurance market. The purpose of this investigation is to highlight possible adverse effects of this lack of harmonization by providing, at the same time, useful suggestions to counteract them for the forthcoming launch of the procedure of revising the Directive 2002/92/EC. The method of investigation used consists in the comparison of the current EU rules on reinsurance intermediaries with those applicable in the U.S. that are more detailed, while regulating intermediaries performing similar functions, in a highly sophisticated market that has the same need of protection as the European one.

The Geneva Papers (2010) 35, 200-216. doi:10.1057/gpp.2010.6

Keywords: reinsurance intermediaries; reinsurance regulation; unfair practices; contingent commissions; solvency

\section{Introduction}

Reinsurance is one of the most "global" businesses because of the need to provide adequate coverage - in terms of expertise relating to the protection necessary to cover the risk and amount of coverage - for risks underwritten in different areas of the world. ${ }^{1}$ Intermediaries are still playing an important role because they provide an efficient way to match insurers' need for coverage and the corresponding reinsurers' answers, ${ }^{2}$ in spite of insurers' increased use of capital market alternatives and the expansion by direct market reinsurers. ${ }^{3}$ During the last two decades, moreover, the role of the intermediary has evolved from that of a market maker to that of a service provider to clients and insurance companies. ${ }^{4}$ These services include claims management and risk management

\footnotetext{
* I am very grateful to Professors Robert Merkin and Ioannis Rokas, and Antonio Caporale, Principal Attorney-State of Connecticut Insurance Department, for their valuable suggestions and review of this work. Any error or omission is solely my own.

${ }^{1}$ Holzheu and Lechner (2007, p. 877).

2 KPMG (2002, p. 9), Baker (2008), Blumberg et al. (2005[2008]), Henley (2004), McGee (2005), and O’Neil and Woloniecki (2004).

${ }^{3}$ Conning (2007, p.7 f) and Fischer et al. (2006).

${ }^{4}$ The rationale for employing a broker in a reinsurance transaction is explained by the European Commission. Competition DG (2007a, p. 85), Abraham (2005), and Jerry II and Richmond (2007).
} 
services $^{5}$ that go beyond the structuring and placement of insurance coverage ${ }^{6}$ and are often carried out in a worldwide perspective. ${ }^{7}$ Brokers have also developed a strong position in the alternative risk transfer market (captive solutions, etc.), while some of the larger players also provide corporations with employee benefit solutions. ${ }^{8}$

According to the above trend, the mutual recognition and standardisation of regulation and supervision rules is certainly welcomed in the reinsurance sector due to its global nature. ${ }^{9}$ A national regulation of these intermediaries contrasts with the international dimension of their activities and the tendency of regulation to achieve a level playing field in this sector. ${ }^{10}$ This contrast is even more evident in the European Union (EU), where the Directive 2002/92/EC on insurance mediation does not seem fully able to achieve a Single Market.

Therefore, this paper means to identify any gaps in the current harmonized regulation of the EU through a comparison of the EU and U.S. legal framework regulating reinsurance intermediaries. ${ }^{11}$

EU and the U.S. are the largest reinsurance markets in the world. ${ }^{12}$ Fostering the knowledge of the U.S. regulation system may be useful because it will assist EU legislators in recognising any gaps in comparison with rules of other jurisdiction that provide answers to common problems, the knowledge of which is useful in Europe, since the revision of Directive 2002/92/EC is imminent. ${ }^{13}$ In addition, the gradual creation of uniform, or at least equivalent, rules both in EU and the U.S. is a preliminary step to the possibility that these laws could proceed to a mutual recognition of their respective supervisory rules, ${ }^{14}$ thus also eliminating existing barriers to carry on business in the other territory: EU or the U.S. ${ }^{15}$

${ }^{5}$ A list of these services is available in SIGMA (2004, p. 5).

${ }^{6}$ Colinvaux \& Merkin's (2008, pp. 40, $190 \mathrm{ff}$ ), about the impact of the changed role of intermediaries [brokers] on the rules concerning their responsibilities.

${ }^{7}$ Henley $(2004$, p. 443 f).

${ }^{8}$ SIGMA (2004, p. 3) and Merkin (2006).

${ }^{9}$ For an analysis of the costs arising from asymmetries in the regulation of insurance distribution, see Baranoff et al. (2000, p. $94 \mathrm{ff})$.

${ }^{10}$ SIGMA (2004, p. 5 f).

${ }^{11}$ See also Booth and Morrison (2007, p. 38 ff), Cooper and Dorfman (2004, p. 3 ff), and Cooper and Dorfman (2003, p. $21 \mathrm{ff})$.

${ }^{12}$ Holzheu and Lechner (2007, p. $\left.891 \mathrm{ff}\right)$.

${ }^{13}$ Knowledge of EU regulatory framework might be useful also in the U.S., where the "battle" to rebuild the regulation of the financial system has started. The most recent legislation is the "Insurance Information Act of 2009" (House Resolution 2609) which passed the House Financial Services Committee on 2 December 2009 and is scheduled for consideration by the House of Representatives later in December. The text, summary and current status of any federal legislation can be easily searched through the Library of Congress' website, http://thomas.loc.gov/, while a survey of the recent developments in the insurance regulation of the U.S. is provided by Dickhaus and Sacks (2007, p. $571 \mathrm{ff})$.

${ }^{14}$ To this purpose, see IAIS (2008), which offers to supervisors wishing to recognize another jurisdiction different acceptable assessment to establish the acceptability of a counterpart's regime.

${ }^{15}$ In practice, the big intermediaries are multinationals with branches in many jurisdictions. Therefore, competition has been achieved not by direct selling but rather by the establishment of branches in overseas territories: for example, a U.S. intermediary wishing to place a risk in Europe will not do so directly, but will use a subsidiary if he has one, or a local placing broker if he does not. See Colinvaux \& Merkin's (2008, pp. 40, 832 f), Butler, and Merkin (2006, pp. 40, 267 ff). 


\section{What is the rationale of the regulation of reinsurance intermediaries?}

A consideration of the supervision objectives inherent in the regulation of reinsurance, shows that traditionally the principal purpose of regulation revolves around (a) ensuring that there is confidence in reinsurers' ability to meet their obligations; and (b) achieving an appropriate degree of protection for customers of ceding companies. ${ }^{16}$

As it relates to reinsurers, prudent supervision attempts to minimise the instances of reinsurers' insolvencies, which in turn satisfies the need for protection of the interests of the policy-holders. ${ }^{17}$ Because of this objective, regulation of reinsurers is limited to oversight of their financial conditions only and, with few exceptions, does not extend to issues related to market conduct, or matters relating to contract terms, conditions, and tariffs. ${ }^{18}$

As regards intermediaries, the rationale for their regulation is: (a) to control the manner in which client money is handled, given that intermediary control both premiums and claims; $(b)$ to ensure independence, or at least disclosure of any links with insurers; and $(c)$ to maintain their solvency so that they can satisfy claims against them if their error causes the client not to have appropriate (re)insurance coverage. ${ }^{19}$

Effective regulation should maintain the stability of the insurance market and, at the same time, promote fair competition. ${ }^{20}$ This means that the regulation must focus on the relationship between intermediaries and their principals, ensuring that intermediaries' duties are always defined and clearly identifiable, ${ }^{21}$ but also means that regulation should not overlook the impact of intermediaries' misconduct towards third parties. Of course, the rules applicable to reinsurance intermediaries should not necessarily replicate exactly those for insurance intermediaries, since the needs for protection met by each of these disciplines may not be identical, even if the common risk of reinsurance undertakings declaring bankruptcy and the consequent effects this would have on the first insured should not be neglected. ${ }^{22}$ Notwithstanding that insurers' customers do not have any contractual relationship with the reinsurance intermediaries, the business conduct of these intermediaries may have a strong negative impact also on the contractual relationship the customers have with their own insurers ${ }^{23}$ as I try to explain in more detail later. Regulatory approach should prevent improper business conduct, or at least its negative impact, from occurring, although it must distinguish between rules that protect the interests concerning only the

${ }^{16}$ IAIS (2008, p. 5).

${ }^{17}$ KPMG (2002, p. 39).

${ }^{18}$ Hsin-Chun Wang (2003, p. 17).

${ }^{19}$ Schwab et al. (1995, p. 487), Hsin-Chun Wang (2003, p. 83), and Henley (2004, p. 444).

${ }^{20}$ Hsin-Chun Wang (2003, p. 112).

${ }^{21}$ With reference to insurance intermediaries, Eckardt (2007, p. $112 \mathrm{ff}$ ) underlines that market forces set only weak incentives for such intermediaries to provide high quality services.

${ }^{22}$ Moreover, there are a number of small insurance companies, which rely on big reinsurance intermediaries to place the risk to reinsurance undertakings that the intermediaries have chosen. In this regard, see Hsin-Chun Wang (2003, p. 89 ff).

${ }^{23}$ Regan and Tennyson (2000, p. 743$)$ point out that: "Given the nature of information problems in insurance markets, it is not clear that the market alone will provide sufficient information to insurance consumers. Hence, government intervention could improve the working of market". 
relationship between consumers and insurance undertakings, ${ }^{24}$ and rules that promote transparency in the reinsurance market also in the interest of consumers and insurance undertakings. 25

On the basis of the above considerations, the next following section seeks to outline the main characteristics of EU and U.S. regulations related to reinsurance intermediaries providing a general framework at the subsection "the framework", whereas subsections "The detailed rules: Access" and "The detailed rule: Business conduct" will consider the provisions of each of them in more detail and the findings on those profiles are summarised in subsection "First conclusions".

\section{Comparing EU to U.S. regulation regarding reinsurance intermediaries}

\section{The framework}

From a general point of view, insurance regulation in the EU is characterized by uniform and compulsory rules issued by the EU and effective throughout the $27 \mathrm{EU}$ Member States, ${ }^{26}$ whereas U.S. regulation is based on the laws of each individual State, and the Model Laws developed by the National Association of Insurance Commissioners (NAIC) are not compulsory to each State. ${ }^{27}$ Therefore, according to this scheme, uniform rules also on reinsurance intermediaries and their activity should be provided by the Directive 2002/92/EC on insurance mediation. In contrast, the possibility of remarkable differences between various State laws relating to intermediaries can be supposed in the U.S. because the NAIC Model Act is not compulsory for each State, although its purpose is to encourage and promote uniformity among the various State laws. Both regulations, in any case, are focused on a State (U.S.) or a Single Market (EU) perspective, a cross border outlook is missing and reinsurance intermediaries are not permitted to conduct business in either EU or the U.S. unless they are based in, and under jurisdiction of, some of the EU or U.S. States.

${ }^{24}$ Reinsurer and ceding insurer, in fact, are generally expected to be knowledgeable about the insurance business. Therefore, the oversight necessary in primary insurance to protect consumer interests is not essential in the reinsurance business.

${ }^{25}$ O'Neil and Woloniecki (2004, p. 523) underline that "there is a sense that reinsurance intermediaries do not require the same amount of regulation and supervision as insurance intermediaries because reinsurance intermediaries deal with people already in the insurance business not 'lay' clients", but their conclusion is that "We cannot see that they can be so different, insurance intermediary to reinsurance intermediary and the cost of framing and regulating a two-tier system and its effect on the mobility of individuals admitted for one and not the other, argues against it". A different opinion seems to be expressed from Hsin-Chun Wang (2003, p. 113): "While the reinsurance intermediary generally deals with professional enterprises, it is suggested that differences between the reinsurance intermediary and insurance intermediary should be drawn and the flexibility of the regulation should be enhanced to prevent the distortion of reinsurance business".

${ }^{26}$ McGee (2005, p. 393 ff). See also CEPS Task Force (2006, p. $\left.60 \mathrm{ff}\right)$ and; for an economic approach to the Single Insurance Market, Klumpes et al. (2007, p. 790 ff).

${ }^{27}$ Baker (2008, p. 651 ff), Jerry II and Richmond (2007, p. 64 ff), Fischer et al. (2006, p. 187 ff), Blumberg et al. (2005[2008], § 128.01, 128-123 ff), Abraham (2005, p. 104 ff), and Henderson and Jerry II (2001, p. $171 \mathrm{ff})$. 
204

From a historical perspective, the EU approach focuses on intermediary activity, ${ }^{28}$ because this is the way to overcome the substantial differences between national provisions, which created barriers, to the taking-up and pursuit of the activities of reinsurance (and insurance) intermediaries in the EU Single Market, in spite of the former Council Directive 77/92/EEC of 13 December 1976. ${ }^{29}$ The Directive 2002/92/ EC, however, distinguishes between access rules and business conduct rules: the former are used to so-called Single Passport for all intermediaries, insurance and reinsurance, the latter concern only the insurance intermediaries, with the exception of the large risks.

U.S. regulation, instead, was developed after a 1980 bankruptcy court decision stemming from the failure of a large reinsurance intermediary: Pritchard \& Baird, Inc. ${ }^{30}$ This regulation was drafted by NAIC in the $1980 \mathrm{~s}$ after the initiative of the State of New York - above all the Regulation $98^{31}$ - on two specific categories of intermediaries: reinsurance intermediary-broker $(\mathrm{RB}),{ }^{32}$ and reinsurance intermediarymanager (RM) ${ }^{33}$ Different rules are applicable to each of these categories, which are considered to undertake separate and distinct activities, although the Model Act does not set out any rule that would prevent a person or entity from obtaining licenses to perform both activities. ${ }^{34}$

Unlike the U.S. law, then, according to EU law we might have a unique intermediary both placing reinsurance cessions or retrocessions and managing the assumed reinsurance business. This more "flexible" approach, however, is not supported by specific rules related to these activities as in the U.S. regulations. Comparing EU and U.S. regulations, therefore, we could have an example of over regulation (i.e. U.S.) or under regulation (i.e. EU), because U.S. detailed provisions might be seen as an excess, or EU flexibility as a lack, of regulation. Of course, it may be that both the current regulations are not adequate to manage the risks related to

${ }^{28}$ Under the art. 2, n. 6 of Directive 2002/92/EC, in fact, reinsurance intermediary "means any natural or legal person who, for remuneration, takes up or pursues reinsurance mediation", namely "the activities of introducing, proposing or carrying out other work preparatory to the conclusion of contracts of reinsurance, or of concluding such contracts, or of assisting in the administration and performance of such contracts, in particular in the event of a claim" (see art. 2, n. 4).

${ }^{29}$ The full text of this Directive, no longer in force and repealed by the Directive 2002/92/EC, is available at www.ec.europa.eu/internal_market/insurance/reinsurance_en.htm.

${ }^{30}$ Schwab et al. (1995, p.510) and Hsin-Chun Wang (2003, p. 95 ff).

${ }^{31}$ Schwab et al. $(1995$, p. 514 f).

${ }^{32}$ Under Section 2, letter $f$ ), reinsurance intermediary-broker (RB) means a person, other than an officer or employee of the ceding insurer, firm, association or corporation who solicits, negotiates or places reinsurance cessions or retrocessions on behalf of a ceding insurer without acting as a reinsurance intermediary-manager (RM) on behalf of the insurer.

${ }^{33}$ Under Section 2, letter $g$ ), reinsurance intermediary - manager (RM) means a person, firm, association or corporation, whether know as a RM, manager or the similar term, who as authority to bind or manages all or part of the assumed reinsurance business of a reinsurer (including the management of a separate division, department, or underwriting office) and acts as an agent for the reinsurer, except the subjects (people or legal entities) identified there.

${ }^{34}$ Jerry II and Richmond (2007, p. 1024), besides, point out that the distinction between "reinsurance intermediaries" and "reinsurance brokers" is "unhelpful and unclear, and these terms are interchangeable". 
reinsurance intermediaries' activity identifying, in this case, a lack of proper rules, in excess or defect, in either law.

\section{The detailed rules: Access}

As noted above, the goals of a viable regulation of reinsurance intermediaries are to maintain the stability of insurance markets and to promote fair competition. Bearing this in mind, the next two sections will examine EU and U.S. models of regulation in detail and will distinguish between access rules and business conduct rules.

Both these regulatory systems adopt an approach that requires proper authorisation under the form of a licensing procedure (U.S.), or registration procedure (EU), with intermediaries required to obtain the proper authorisation to carry on their business, ${ }^{35}$ and insurance and reinsurance undertakings prohibited from using services of nonlicensed/unregistered intermediaries. ${ }^{36}$ The rationale for this provision is that the above licensing/certificating requirements should be able to assess the fitness and propriety of management, consisting of the competence, practical experience, and suitability of key staff including the major shareholders. ${ }^{37}$ To this purpose, art. 4 of Directive 2002/92/EC requests reinsurance intermediaries to possess appropriate knowledge and ability, as determined by the home Member State of the intermediary, and to be of a good reputation; ${ }^{38}$ while, for the U.S., these standards depend on discretionary judgment of each State's insurance commissioner. ${ }^{39}$

The EU model is less discretionary than the U.S./NAIC model because it requires detailed provisions on knowledge and ability, whose function is also to restrict the discretion of the supervisor, thus avoiding decisions based on a policy of restriction to the access of new intermediaries, which would ultimately lead to anti-competitiveness. However, the contents of these provisions are not uniform throughout the EU Single Market. The Member States and their supervisory authorities must trust each other in the absence of uniform and detailed requirements because the authorisation given to an intermediary based in a Member State (home state), in accordance with the rules of that State, enables its activity in the others (host states) in accordance with the principles of freedom of establishment and freedom to provide services. ${ }^{40}$

\footnotetext{
${ }^{35}$ Section 3 of the Reinsurance Intermediary Model Act and art. 3, par. 1, Directive 2002/92/EC.

${ }^{36}$ Section 16 of the Reinsurance Intermediary Model Act and art. 8, par. 2, Directive 2002/92/EC.

${ }^{37}$ Hsin-Chun Wang (2003, p. 117 f).

${ }^{38}$ Art. 4, par. 2, besides, statues that: "as a minimum, they shall have a clean police record or any other national equivalent in relation to serious criminal offences linked to crimes against property or other crimes related to financial activities and they should not have previously been declared bankrupt, unless they have been rehabilitated in accordance with national law".

${ }^{39}$ See Section 3 letter $E$ ), of Reinsurance Intermediary Model Act, where: "The commissioner may refuse a reinsurance intermediary license if, in his or her judgment, the applicant, any one named on the applications, or any member, principal, officer or director of the applicant, is not trustworthy, or that any controlling person of such applicant is not trustworthy to act as reinsurance intermediary (...). Upon written request therefore, the commissioner will furnish a summary of the basis of the refusal to issue a license, which document shall be privileged and not subject to [cite the applicable freedom of information law]".

${ }^{40}$ On supervisors' liability in the EU, Coussy (2006, p. $\left.105 \mathrm{ff}\right)$.
} 
206

The U.S./NAIC Model Act, instead, is characterized by the distinction between intermediaries who are residents (of the State) and those who are non-residents. This scheme tends, apparently, to be in contrast with the solution adopted in the Reinsurance Regulatory Modernization Act of $2009,{ }^{41}$ which provided for the mutual recognition of the rules of supervision of reinsurance undertakings, ${ }^{42}$ because the supervision on intermediaries does not seem to present features which would exclude any form of mutual recognition. The contrast - as stated earlier - is only apparent. In fact, Section 13 of the Model Act says that the insurance commissioner shall waive any requirements for a non-resident license applicant with a valid license from the applicant's home state, if this one awards non-resident licenses to residents of this state on the same basis. In addition, States should not require an applicant for a non-resident license either to satisfy any additional requirement for a license, except as allowed by the Act, or to pay fees that are so disparate from the resident fees that they impose a barrier to entry, in accordance with Public Law $\mathrm{N}^{\mathrm{O}}$ 106-102 (the "Gramm-Leach-Bliley Act").

Furthermore, the U.S./NAIC Model Act allows each Commissioner', in his or her judgment, to refuse to grant the license if any controlling person of the applicant intermediary is not trustworthy to act as a reinsurance intermediary. ${ }^{43}$ This rule could be introduced by EU Member States exercising their national regulatory power, although it is not the object of a specific, uniform, provision in the Directive in spite of the importance of this rule having been pointed out from a supervisory point of view. ${ }^{44}$

Moreover, both systems require the intermediary to hold a certain amount of professional indemnity insurance against any legal liability arising from professional negligence in connection with the activity. ${ }^{45}$ In the U.S./NAIC Model Act, however, this requirement applies only to reinsurance managers. ${ }^{46}$ Moreover, under U.S. law, the commissioner may also require a resident reinsurance manager to file a bond in an amount acceptable to the supervisor for the protection of the reinsurer. At the same time, Directive 2002/92/EC provides that the Member State shall take a measure as a requirement to have financial capacity amounting, on a permanent basis, to 4 per cent of the sum of annual premiums received, subject to a minimum of EUR $15,000 .{ }^{47}$ This provision, however, is referred only to insurance intermediaries, although each

41 This legislation was adopted by the NAIC Reinsurance Task Force on 15 September 2009 and it is available at www.naic.org/committees_e_reinsurance.htm.

42 The above NAIC proposal would create two new classes of reinsurers authorised to operate in the United States: U.S.-domiciled national reinsurers and non-U.S.-based port of entry reinsurers, and would introduce modified collateral requirements for eligible reinsurers. The proposal would establish a new framework for state-based reinsurance regulation founded on the concepts of supervisory recognition, single-state licensure for U.S. reinsurers and single-state certification for non-U.S. reinsurers from approved jurisdictions.

${ }^{43}$ Section 3, subsection $E$ ), adds: “or (...) has given cause for revocation or suspension of such license, or has failed to comply with any prerequisite for the issuance of such license".

${ }^{44}$ Hsin-Chun Wang (2003, p. 113).

${ }^{45}$ Schwab et al. (1995, p. 521) point out that this rule provide protection in the event of insolvency, not only of the intermediary, but also the cedent or reinsurer in the event of insolvency of the other.

${ }^{46}$ Section 3, subsection $C(2)$.

47 Art. 4, par. 4, let. $b$ ). 
Member State may extend this requirement to reinsurance intermediaries registered within their jurisdiction. ${ }^{48}$

\section{The detailed rules: Business conduct}

In carrying out its activity, the intermediary must observe the rules of conduct of the market in which business is undertaken.

As regards these rules, the approach adopted by the U.S./NAIC model - as noted above - is to require the contract between a reinsurance intermediary and his principal to contain specific provisions addressing legal duties and relevant rights. ${ }^{49}$ This model ensures the protection of the ceding insurers and reinsurers by the means of compulsory provisions in the relevant arrangements. ${ }^{50}$

The U.S. approach has been criticized because it could result in a legal challenge on the ground that the regulation may interfere with the private contractual relationship between the reinsurance intermediaries and their principals. Consequently, this may impede the flexibility of reinsurance transactions and increase the transaction costs. ${ }^{51}$ This statement, however, has not been supported by a cost/benefit analysis showing that there is in fact a cost increase and that the costs are higher than the benefits. Therefore, the criticism has to be appreciated as a signal of a danger that needs to be verified on an empirical basis.

Conversely, there is no evidence in any economic survey that the absence of business conduct rules is the optimal solution for the intermediaries operating in an efficient reinsurance market. The Financial Services Authority (FSA), the supervisory financial authority of the U.K., namely the largest reinsurance market within EU, challenged the insurance industry at the end of 2004 to end the practice so-called "deal now, detail later" and set a deadline of two years to find an industry solution or face regulatory intervention. ${ }^{52}$ In particular the FSA required for all insurance transactions, including those involving reinsurance, ${ }^{53}$ the contract certainty, that is the complete and final agreement of all terms between the insured and insurer by the time that they enter into the contract, with contract documentation provided promptly thereafter. ${ }^{54}$ In delegating the task to come up with a solution to the insurance industry, the FSA opted for a market-based solution where it can use its influence rather than its formal powers to bring about change. Aside from the possibility,

48 Art. 4, par. 6.

${ }^{49}$ On the reinsurance intermediaries liability under U.S. law, see Richmond (2006, p. $\left.63 \mathrm{ff}\right)$ and Schwab et al. (1995, p. $511 \mathrm{ff})$.

${ }^{50}$ See Sections 4 and 5 of the Reinsurance Intermediary Model Act as regards the transactions between a reinsurance broker and the insurer it represents in such capacity, and the Sections 7 and 8 for those relating to reinsurance manager and the reinsurer. See also Schwab et al. (1995, p. $518 \mathrm{ff})$.

${ }^{51}$ Hsin-Chun Wang (2003, p.114).

${ }^{52}$ Colinvaux \& Merkin's (2008, pp. 10, 277 f).

${ }^{53}$ Colinvaux \& Merkin's (2008, pp. 10, 278).

${ }^{54}$ The above definition is offered by the Contract Certainty Code of Practice published by Lloyd's, the International Underwriting Association (IUA), the Lloyd's Market Association (LMA), Association of British Insurers (ABI), British Insurance Brokers' Association (BIBA), Institute of Insurance Brokers (IIB), and London Market Insurance Brokers' Committee (LMBC). See also Hogarth (2008, p. 527). 
or the will, for the other supervisory authorities of the EU Member States to replay the FSA approach, it seems almost evident that "contract certainty" is also a rule per se: it must be observed by undertakings and intermediaries and the supervisor must enforce it. $^{55}$

Therefore, it is perplexing that the Directive 2002/92/EC has no provision on the business conduct of reinsurance intermediaries. Even the weak rules on conflict of interest, which require (insurance) intermediaries to disclose to costumers the relationship with insurance undertakings, ${ }^{56}$ do not apply to reinsurance intermediaries. ${ }^{57}$ Unquestionably recital n. 21 of the Directive 2002/92/EC says that there is less of a need to require that information be disclosed when the customer is a company seeking reinsurance. Nevertheless, this does not mean that no information shall be provided by reinsurance intermediaries. The absence of rules on this specific issue appears to be in conflict with recital $\mathrm{N}^{\circ} 17$, under which the cooperation and exchange of information between competent authorities are essential in order to protect customers and ensure the soundness of (insurance and) reinsurance business in the Single Market. Under the principle of mutual recognition, in fact, the cooperation between the supervisory authorities must relate to profiles concerning the pursuit of activity, not the access. It is difficult to envision mutual recognition taking place unless the business conduct rules of reinsurance intermediaries are entirely harmonized. Besides, requiring intermediaries to possess appropriate knowledge and ability art. 4, par. 1, of the Directive 2002/92/EC seems also to fix the principle that intermediaries' activity must be carried out according to these skills: otherwise, the above requirement does not make sense. Because the objective is to create a Single Market, this principle should have been specified in detail by the Directive, in a way that makes it possible, in any case, for an intermediary to meet high standards of competence and integrity in carrying on its business. ${ }^{58}$ Moreover, this specification would be useful to guide the decisions of the Courts, ${ }^{59}$ in addition to preventing improper conduct of intermediaries.

Unlike the U.S./NAIC Model Act, again, Directive 2002/92/EC does not set any rule that provides for clear communication between the parties and for documentation about the transaction with the principal, nor does it require the intermediary to provide an account of claim information and fund collected. ${ }^{60}$ Moreover, under the U.S./NAIC Model Act all funds collected for the reinsurer's account are required to be held by the reinsurance intermediary in a fiduciary capacity in qualified financial institutions. ${ }^{61}$ The provision of a separate account is one of the measures taken into

${ }^{55}$ Hogarth (2008, p. 527 f).

56 Art. 12, par. 1, let. $c$ ) and $d$ ).

${ }^{57}$ As regards the position of conflict of interest of a broker who acts for an insured in placing insurance, and then for insurers in placing reinsurance, see Merkin (2006, p. 531).

${ }^{58}$ Alternatively, the Directive would specifically provide that such rules are established by the insurance industry at European level. This choice, however, should be accompanied by the principles upon which the self-regulation should be guided and, above all, by identifying the interests that must be protected. For an example of self-regulation, although currently it is not binding, see BIPAR (2008).

${ }^{59}$ A list of these issues can be read in Hsin-Chun Wang (2003, p. 118).

${ }^{60}$ With reference to the U.S. Model Act, instead, see Schwab et al. (1995, p. 518 ff).

${ }^{61}$ Schwab et al. (1995, p. 521). 
account by art. 4 of Directive 2002/92/EC to protect customers against the inability of the intermediary to transfer the premium to the insurance undertaking, or to transfer the amount of claim or return premium to the insured. Surprisingly, this provision is applicable only to insurance intermediaries ignoring, as well, the role that it can play in preventing a misconduct of reinsurance intermediaries from a supervisory point of view. ${ }^{62}$ In addition, some intermediaries could also be authorised to perform both reinsurance and insurance mediation, with the obligation to keep a separate account for only the last one of those activities.

\section{First conclusions}

Summarising the findings outlined until now, the comparison between EU and U.S. regulations on reinsurance intermediaries points out that the EU approach seems more effective as regards the rules on the access to the activity because they are less discretionary than the U.S. rules and, therefore, more pro-competitive although not uniform. However, Directive 2002/92/EC does not contain any rules related to the business conduct of the intermediaries, so the EU regulation is set quite in antithesis to U.S. regulations which try to clarify the role assumed by the intermediary in respect of its principal: depending on the case, insurer or the reinsurer. Under U.S./NAIC Model Act, in fact, the contractual relationship between the intermediary and its principal must specify a series of obligations by the parties; and the flow of money managed by an intermediary on behalf of its principal must be done via a separate account.

Therefore, it would be advisable that (at least) a cost/benefit analysis should be performed to support any persistent choice in the EU for a regulation that aims to protect policy-holders, with rules that tend to discipline their relationship with the insurers, but fail to deal with the relationship that exists between the latter and the reinsurers despite their connection to each other.

In addition, it was revealed that the Directive 2002/92/EC contains a definition of mediation (reinsurance and insurance), but establishes rules governing intermediaries who engaged in these activities. Therefore, each Member State is allowed to distinguish the previously mentioned activities reserving their performance to different categories of intermediaries: insurance and reinsurance.

The consequence of this distinction will be the application of different rules for access and business conduct; while regulatory arbitrage or interpretative uncertainty could be possible risks, if such rules were distinct without any justification. ${ }^{63}$

Where a global policy is issued providing cover over a global group of companies, fronted policies may be issued locally for each local affiliated company. In such cases, the undertaking that provides the cover is the insurer who issues the global policy and, at the same time, that undertaking is also the reinsurer of the respective fronted local policies. However, in reality, the reinsurer is the actual first insurer since the fronted

${ }^{62}$ Hsin-Chun Wang (2003, p.117), where he points out that insurance monies held by the intermediary should be maintained in a segregated account and separated from the general assets of the intermediary avoiding, in the event of its bankruptcy, to use these accounts to reimburse other creditors.

${ }^{63}$ See Regan and Tennyson (2000, p. 740) concerning the possible impact on distribution costs of differential requirements for independent versus tied agents. 
policy is merely issued for regulatory purposes. Since the reinsurance intermediary acts as a first insurance broker, the question is as follows: Should the intermediary be subject to the same principles that apply to first insurance broker?

The finding that the broker is acting in a dual capacity ${ }^{64}$ is not an optimal solution for those Member States that have separate categories of intermediaries in accordance with such a possibility offered by said Directive. Nevertheless, a response should be provided by the EU regulation, if it aspires to build an efficient Single Market.

\section{Towards a new regulatory approach?}

\section{A "different" link between the reinsurance and insurance market}

The impact of reinsurance market practices on the relationship between insurer and policy-holder has been almost neglected by regulators (and supervisors), which do not seem to take into account the costs incurred by the policy-holders in procuring insurance coverage.

Anti-competitive practices in the reinsurance market could conceivably raise the costs for the insurers buying reinsurance, which are ultimately paid by the policyholders. ${ }^{65}$

Therefore, a lack of competitiveness in the reinsurance market would also have an impact on the economic substance of the underlying insurance contract between insurer and policy-holder.

The awareness of this impact is emerging, however, both in the EU and in the U.S., as we highlight in the next subsections.

\section{The Sector Inquiry on Business Insurance and the reinsurance market}

In the White paper on Financial Services Policy (2005-2010), ${ }^{66}$ the EU also planned to make a maximum use of policy synergies between financial services and other policy areas, particularly competition (sectoral enquiries), consumer policy (consumer protection, contract law), and taxation. ${ }^{67}$ Therefore EU Commission-DG Competition, after an interim report of January $2007,{ }^{68}$ posted the final version of the Inquiry into the European business insurance sector on December $2007 .^{69}$ The Inquiry aimed at better understanding the functioning of the writing and distribution of business insurance with a view to ultimately identify any concrete restrictive practices or

\footnotetext{
${ }^{64}$ See Henley (2004, p. 471).

${ }^{65}$ Mainly with reference to the competitive structure of retail brokers, see Cummins and Doherty (2006, p. $370 \mathrm{ff})$.

${ }^{66}$ The White Paper is available at www.europa.eu/internal_market.

${ }^{67}$ White Paper on Financial Services Policy, at point 2.7.

${ }^{68}$ The rationale for employing a broker in a reinsurance transaction is explained by the European Commission. Competition DG (2007a, p. 85).

${ }^{69}$ European Commission. Competition DG (2007b).
} 
distortions of competition that may fall within the scope of articles 81 or 82 of the Treaty. $^{70}$ This might further lead to follow-up enforcement action either by the Commission or by national competition authorities within the European Competition Network. $^{71}$

Looking at its findings, in the view of the Commission services, the agency nature of any agreement between broker and customer does not have the effect of releasing the broker, in its capacity as an independent undertaking, from the obligation to respect the rules on competition. ${ }^{72}$ Therefore, the relationship between insurer and broker does not fall per se $e^{72}$ under the exceptions to article 81 of the Treaty, fixed by $\$ \S 12 \mathrm{ff}$ of the Commission's Guidelines on Vertical Restraints. ${ }^{73}$

According to this premise, the survey also pointed out that the so-called Best Terms and Conditions clauses $(\mathrm{BTC})^{74}$ - which seems to be a practice present in all lines of reinsurance within the EU, albeit in different degrees ${ }^{75}$ - have the principal effect of aligning terms, conditions of coverage and premiums at levels which are, to a varying degree, detrimental to the (re)insured and which are correspondingly more favourable to the (re)insurers. Therefore, it would be desirable for brokers to systematically discuss with their clients all available options rather than exclude certain options in advance, merely on the grounds that such options are contrary to established market practice.

The harmonization of premiums at the highest level would also lead to higher brokerage fees for brokers in cases where the brokerage fee is calculated as a proportion of the premium. ${ }^{76}$ In this case, brokers might not have an incentive to challenge the prevailing market practice.

The conclusion of the survey is that brokers could be parties, in certain instances, to arrangements which fall within the scope of article 81(1), failing to stimulate possible competition on price, even in the absence of a BTC clause; while it is a matter of factual circumstances, which can only be fully determined on a case-by-case basis, whether there are efficiencies which meet the criteria of article 81(3).

${ }^{70}$ See the Consultation paper launched in April 2008 by the EU Commission on the functioning of the Insurance Block Exemption Regulation, from http://ec.europa.eu/comm/competition/sector/financial_ services/overview/en.html.

${ }^{71}$ European Commission. Competition DG (2007b, p. 1).

${ }^{72}$ European Commission. Competition DG (2007b, p. 37).

${ }^{73}$ Although exceptions remain possible: European Commission. Competition DG (2007b, p. 37 f).

${ }^{74}$ Best Terms and Conditions clauses were defined by the European Commission. Competition DG (2007b, p. $21 \mathrm{f}$ ), as follows: "Any stipulation, whether written or oral, introduced at any stage of the negotiation of a reinsurance contract, by means of which a (re)insurer $A$ obtains, seeks to obtain or acquires the right, under certain circumstances, to obtain an alignment of its proposed or agreed terms and conditions, in particular the premium, to the terms and conditions ultimately obtained by any other (re)insurer $B$ participating in (re)insuring the same (re)insured as $A$, in the event that the latter terms are more favorable to the (re)insurer, than the terms and conditions which $A$ initially offered or subsequently agreed".

75 European Commission. Competition DG (2007b, pp. 24 f, 29).

${ }^{76}$ European Commission. Competition DG (2007b, p. 31) adds: "and possibly also when the broker is remunerated on a fee basis, if in addition he receives contingent commissions based on profitability of the business placed". 
212

The "turned on lighthouse" by the EU Commission, on the reinsurance market practices and the possible behaviours of the intermediaries, shows the impact that both could have on the economic substance of the insurance contract between insurers and policy-holders, in terms of higher costs for the latter arising from the lack of competition. The current rules may be able to counteract such anti-competitive behaviours, perhaps on the basis of the next review of the Insurance Block Exemption Regulation. ${ }^{77}$ The survey, however, also pointed out the aversion of the BTC to the principle of contract certainty, which is considered as the "polar star" by the FSA in its market-based approach. In the shared view of the Commission services, in fact, the BTC clauses introduce an element of contractual uncertainty since they create ambiguity on the exact terms and conditions which will apply in the event of a claim. ${ }^{78}$ This is another element which should lead to rethinking the absence of (harmonized) business conduct rules in the current version of the Directive 2002/92/EC.

\section{The complaint promoted by the Attorney General of the State of Connecticut}

On the other shore of the Atlantic Ocean, on October 2007, the Attorney General of the State of Connecticut filed a complaint against a reinsurance broker and several reinsurers, for anti-competitive practice that illegally inflated insurance costs for insurance companies and consumers nationwide. ${ }^{79}$ According to the lawsuit, broker Guy Carpenter, conspiring with numerous reinsurers to exploit its position as a dominant reinsurance broker, fixed prices, shut out competitors, manipulated the markets and substantially increased profits in the lucrative reinsurance market. In particular, this company and its co-conspirators would have allegedly created an illusion of competition - a faux functioning market. According to the Attorney General, they raised costs for insurance companies, which ultimately were paid by businesses, homeowners and taxpayers. Guy Carpenter allegedly funneled lucrative business to select inner circles of reinsurers - or "facilities" - in exchange for excessive fees and other benefits from these reinsurers (i.e. contingent or profit commissions). Reinsurers included in these facilities agreed not to compete against the prices and terms set by Guy Carpenter or another "lead reinsurer" and instead agreed to be bound by the same prices and terms as the other participants. Apart from the alleged violation of the Connecticut Antitrust Act, the complaint alleges that Guy Carpenter made numerous material omissions to its clients to whom the above broker had a duty to disclose by virtue of Guy Carpenter's fiduciary and contractual obligations to them. In so doing, Guy Carpenter allegedly violated the Connecticut Unfair Trade Practice Act because its acts or practices misrepresented the nature, characteristics,

${ }^{77}$ Regulation (EC) No 358/2003, in fact, will expire on 31 March 2010. Consultation launched by the EU Commission and replies are available at http://ec.europa.eu/competition/sectors/financial_services/ insurance.html.

${ }^{78}$ European Commission. Competition DG (2007b, p. 24), noted that: "It could, thereby, lead to what has been termed 'underwriting after the event' where a reinsurer is free to pick and choose between any of the divergent conditions of its co-reinsurers in the event of a claim".

${ }^{79}$ The complaint is available at http://www.ct.gov/ag/lib/ag/antitrust/reinsurancecomplaint.pdf. 
benefits, and qualities of the services provided by Guy Carpenter. According to the complaint, again, the above broker steered hundreds of millions of dollars of business over a 50-year period to a company in which Guy Carpenter has a direct ownership interest and management role - a company which did not have any employees and whose office was located physically within Guy Carpenter's Philadelphia officefailing to disclose to clients its interest in the company. ${ }^{80}$ On a more general level, indeed, the Attorney General investigation has found that the so-called BTC clause is anti-competitive, thus coinciding with the views expressed in this regard by the EU Commission.

A decision on the above lawsuit is pending, ${ }^{81}$ but this case shows that reinsurance market practices could be inconsistent with competition law and create higher costs for insurers and their clients as a result of anti-competitive practices. Intermediaries, indeed, could have a conflict of interest with their customers because of the existence of contingent or profit commissions payable by reinsurers that would cause intermediaries to steer business to their own reinsurers for their own benefit, while failing to disclose this fact to their customers.

\section{Some conclusions}

A first suggestion from the above U.S. experience is to evaluate the behaviour of reinsurance intermediaries also in terms of compliance with standards aimed at ensuring fair commercial practices. To this purpose, unfortunately, the recent Directive 2005/29/EC of the European Parliament and of the Council of 11 May 2005, concerning unfair business-to-consumer commercial practices in the internal market, does not cover the (direct) relationship reinsurance between intermediaries and insurers and, a fortiori, the (indirect) relationship between these intermediaries and insurers' customers (policy-holders). ${ }^{82}$ According to recital $\mathrm{N}^{\circ}$ 9, however, the Directive does not pre-empt the right of Member States to go beyond its provisions in order to protect the economic interests of consumers of financial services. Domestic rules should attempt to protect consumers from the indirect effect of the relationship between intermediaries and reinsurers; while harmonized rules would have certainly been better to create a competitive Single Market.

Another suggestion about desirable rules concerns the contingent or profit commissions, since the action filed by the Attorney General of the State of Connecticut shows that the problems that can arise in the relationship between insurance undertakings

${ }^{80}$ The scheme also made it easier to place business because - unbeknownst to its clients - Guy Carpenter did not have to seek competitive bids or quotes on behalf of each client. This anti-competitive structure was concealed from Guy Carpenter's clients, who relied on Guy Carpenter to obtain the best reinsurance product at the best price.

${ }^{81}$ On 16 October 2009, an agreement was signed between the Attorney General of the State of Connecticut and The Hartford Financial Services Group Inc. and its subsidiaries, which were involved in the above complaint.

${ }^{82}$ Recital $N^{\circ} 6$, in fact, says that Directive "neither covers nor affects the national laws on unfair commercial practices which harm only competitors' economic interests or which relate to a transaction between traders; taking full account of the principle of subsidiary, Member States will continue to be able to regulate such practices, in conformity with Community law, if they choose to do so". 
and brokers can also be repeated in the reinsurance market. ${ }^{83}$ The Inquiry on Business insurance promoted by the EU Commission, instead, does not deal with the case in which such commissions are paid by the reinsurance undertakings to the brokers. It is desirable, therefore, that the next changes to the Directive 2002/92/EC proposed by the EU Commission also keep in mind of the possible negative effects of such commissions, when paid in the reinsurance market. ${ }^{84}$

\section{Concluding remarks}

The main goal of this paper was to identify any gaps in the current framework of the EU emphasizing the similarities and differences in the regulatory approach to reinsurance intermediaries by the U.S. and EU law. In this way, possible gaps in the EU (and U.S.) law could be better identified and filled, above all if the problems are common to both. The suggestions emerged by this comparison have been different and-it is hoped-useful. In addition, the link between insurance market and reinsurance cannot be ignored by the revised framework of the EU. This does not mean that reinsurance intermediaries should be subject to the same rules applicable to insurance intermediaries, but regulators should be more sensitive to the costs on insurers and insured that spring from the practices of the reinsurance market. At least, a true regulatory harmonization in the EU and the U.S., which is also not "eccentric" in comparison to common problems of both territories, is probably a compulsory step before hypothesizing a mutual recognition of such rules.

\section{References}

Abraham, K.S. (2005) Insurance Law and Regulation: Cases and Materials, New York: Foundation press.

Baker, T. (2008) Insurance Law and Policy, Austin-Boston-Chicago-New York-The Netherlands: Aspen Publishers.

Baranoff, E.G., Baranoff, D. and Sager, T.W. (2000) 'Nonuniform regulatory treatment of broker distribution systems. An impact analysis for life insurers', Journal of Insurance Regulation 19: 94-118.

BIPAR (2008) 'Principles on Transparency in Insurance', June, from www.bipar.eu/Portals/13/Public\% 20paper-2008 BIPAR\%20principles\%20transparency-EN.pdf, accessed 24 April 2009.

Blumberg, P.I., Strasser, K.A., Georgakopoulos, N.L. and Gouvin, E.J. (2005[2008]) Blumberg on Corporate Groups, Vol. 4, Austin-Boston-Chicago-New York-The Netherlands: Aspen Publishers.

Booth, P. and Morrison, A.D. (2007) 'Regulatory competition and life insurance solvency regulation in the European Union and United States', North American Actuarial Journal 11: 23-41.

Butler, J.S. and Merkin, R.M. (2006) Reinsurance Law, London: Thomson Sweet \& Maxwell, Release 69.

Carson, J.M., Dumm, R.E. and Hoyt, R.E. (2007) 'Incentive compensation and the use of contingent commissions: The case of smaller distribution channel members', Journal of Insurance Regulation 25: $53-67$.

${ }^{83}$ On the debate concerning to the contingent commission; see Carson et al. (2007, p. $\left.53 \mathrm{ff}\right)$, Richmond (2007), Schwarcz (2006, p. 289 ff), Fitzpatrick (2006, p. 3041 ff), Cummins and Doherty (2006, p. 359 ff), and Goel (2006, p. $211 \mathrm{ff})$.

${ }^{84}$ Although recent studies that evaluate the solution adopted by some EU Member states like Denmark and Finland, which have introduced the so-called net quoting system, do not seem to take into account contingent commissions paid in the reinsurance market; see Focht et al. (2009). 
Center for European Policy Studies (CEPS) Task Force (2006) The Future of Insurance Regulation and Supervision in the EU. New Developments, New Challenges (November), pp. 1-150, available at http:// shop.ceps.be.

Colinvaux \& Merkin's (2008) Insurance Contract Law, London: Sweet \& Maxwell.

Conning (2007) Property-Casualty Reinsurance Distribution, pp. 1-35.

Cooper, R.W. and Dorfman, M.S. (2003) 'Producer licensing: The trend toward reciprocity in the United States and the European Union', Journal of Insurance Regulation 21: 21-40.

Cooper, R.W. and Dorfman, M.S. (2004) 'Modernizing U.S. insurance regulation: What can be learned from the European Union?' Journal of Insurance Regulation 22: 3-33.

Coussy, H. (2006) '«L'arroseur arrosé» ou quelques consideration sur la responsabilité civile des autorités de surveillance du sectoeur financier', in Etude offert à H. Groutel (ed.), Responsabilité civile et assurances, Paris: LexisNexis Litec, pp. 105-117.

Cummins, J.D. and Doherty, N.A. (2006) 'The economics of insurance intermediaries', Journal of Risk \& Insurance 73: 359-396.

Dickhaus, B.A. and Sacks, D.N. (2007) 'Recent developments in insurance regulation', Tort \& Insurance Law Journal 42: 571-594.

Eckardt, M. (2007) Insurance Intermediation. An Economic Analysis of the Information Services Market, Heidelberg-New York: Physica-Verlag (a Springer Company).

European Commission. Competition DG (2007a) 'Business Insurance Sector Inquiry. Interim Report', January, from www.ec.europa.eu/competition/sectors/financial_services/inquiries/business.html, accessed 24 April 2009.

European Commission. Competition DG (2007b) 'Business Insurance Sector Inquiry. Final Report', December, from www.europa.eu/comm/competition/sector/financial_services/overview/en.html, accessed 24 April 2009.

Fischer, E., Swisher, P.N. and Stempel, J.W. (2006) Principles of Insurance Law, LexisNexis.

Fitzpatrick, S.M. (2006) 'The small laws: Eliot Spitzer and the way to insurance market reform', Fordham Law Review 74: 3041-3071.

Focht, U., Richter, A. and Schiller, J. (2009) 'Intermediation and Matching in Insurance Markets', from http://ssrn.com/abstract $=1403326$.

Goel, R.K (2006) 'Insurance intermediaries and contractual relations', Applied Financial Economics Letters 2: 211-215.

Henderson, R.C. and Jerry II, R.H. (2001) Insurance Law: Cases and Materials, Lexis Publishing.

Henley, C. (2004) The Law of Insurance Broking, London: Sweet \& Maxwell.

Hogarth, R. (ed.) (2008) Insurance Law for the Construction Industry, New York: Oxford University Press.

Holzheu, T. and Lechner, R. (2007) 'The global reinsurance market', in J.D. Cummins and B. Vernard (eds.) Handbook of International Insurance between Global Dynamics and Local Contingencies, New York: Springer, pp. 877-902.

Hsin-Chun Wang, W. (2003) Reinsurance Regulation. A Contemporary and Comparative Study, London; the Hague; New York: Kluwer Law International.

IAIS (2008) 'Guidance Paper on the Mutual Recognition of Reinsurance Supervision', October, from www.iaisweb.org, accessed 24 April 2009.

Jerry II, R.H. and Richmond, D.R. (2007) Understanding Insurance Law, LexisNexis.

Klumpes, P., Fenn, P., Diacon, S., O'Brien, C. and Yildrim, C. (2007) 'European insurance markets: Recent trends and future regulatory developments', in J.D. Cummins and B. Venard (eds) Handbook of International Insurance between Global Dynamics and Local Contingencies, New York: Springer, pp. $790-848$.

KPMG (2002) 'Study into the Methodologies for Prudential Supervision of Reinsurance with a View to the Possible Establishment of an EU Framework', from http://europa.eu.int/comm/internal_market/en/ finances/insur/index.html, accessed 24 April 2009.

McGee, A. (2005) The Modern Law of Insurance, Butterworth's Law.

Merkin, R. (2006) Colinvaux's Law of Insurance, London: Sweet \& Maxwell.

O'Neil, P.T. and Woloniecki, J.W. (2004) The Law of Reinsurance in England and Bermuda, London: Sweet \& Maxwell.

Regan, L. and Tennyson, S. (2000) 'Insurance distribution systems', in G. Dionne (ed.) Handbook of Insurance, Boston/Dordrecht/London: Kluwer Academic Publishers, pp. 709-748. 
216

Richmond, D.R. (2006) 'Reinsurance intermediaries: Law and litigation', Hawaii Law Review 29: 59-95.

Richmond, D.R. (2007) 'Role of ambiguity - Contingent commissions. A costly misunderstanding: Brokers, contingent commissions, and conflicts that never were', in New Appleman on Insurance: Current Critical Issues in Insurance, Law, Matthew Bender \& Company, Inc.

Schwab, S.W., Gallanis, P.G., Mendelsohn, D.E. and Ritter, B.V. (1995) 'Caught between rocks and hard places: The plight of reinsurance intermediaries under U.S. and English law', Michigan Journal of International Law 16: 485-543.

Schwarcz, D. (2006) 'Beyond disclosure: The case for banning contingent commissions', Yale Law \& Policy Review 25: 289-336.

SIGMA (2004) 'Commercial Insurance and Reinsurance Brokerage. Love thy Middleman', from http://www.swissre.com/pws/research\%20publications/sigma\%20ins.\%20research/commercial\%20insurance\% 20and\%20reinsurance\%20brokerag.html, accessed 24 April 2009.

\section{About the Author}

Pierpaolo Marano is Associate Professor of Commercial Law at the University of Calabria and Professor of Insurance Law at the Catholic University of Milan. 